\title{
PRAVNE POSLJEDICE NEADEKVATNOG TRENINGA I METODA RADA U SPORTU TE ZAKONSKE NOVELE NEKIH NEUTVRĐENIH POJMOVA U SPORTU DE LEGE FERENDA
}

\author{
$U D K: 347: 796$ \\ DOI: $10.31141 /$ zrpfs.2019.56.133.627 \\ Stručni rad \\ Primljeno: 1. 10. 2018.
}

\begin{abstract}
Kompleksnost pravnih odnosa i posebne specifične situacije koje su moguće u sportu i sportskim djelatnostima te akteri takvih situacija zahtijevaju dodatnu pravnu regulaciju i nadopunu postojećih pravnih normi i pravnih akata: sportske, obvezne, građanske, radne, medicinske, kaznene, sudske i drugih pravnih grana, neposredno i posredno vezanih uz sport. Pored svih pravnih normi primjenjivih na sport, zakonodavac je propustio utvrditi i normirati jednu relativno čestu pojavu u modernom sportu, a to su sportske i pravne posljedice neadekvatnog (nestručnog) treninga i metoda rada. To se prvenstveno odnosi na pretreniranost i razne sportske ozljede, kao i na moguće sekundarne povrede osobnosti kao rezultat nestručnog rada (psihološka nestabilnost, depresija sportaša i strah od gubitka sportske karijere). Nestručni rad dovodi kratkoročno do prestanka sportskih aktivnosti zbog pretreniranosti i raznoraznih povreda (sportskih ozljeda i pratećih povreda osobnosti), a dugoročno i do prekida sportske karijere. Potencijalno može biti ugrožena i egzistencija svih osoba involviranih u ovakve slučajeve. Odgovorni krivci u ovakvim slučajevima (treneri, menadžeri, sponzori, liječnici i drugi) moraju snositi pravne posljedice kroz imovinskopravne, kaznenopravne i druge sankcije. Koje su pravne posljedice takvih slučajeva i tko ih je dužan utvrditi, propust je zakonodavne vlasti. Zakonodavac bi trebao pokrenuti inicijativu za uvođenje u pravni sustav novih specijaliziranih sudskih tijela. Takvi bi sportski sudovi bili pravno nadležni za utvrđivanje, pogrešno dijagnosticiranje i sankcioniranje posljedica nestručnog rada u sportu, kao i za sve druge pojave u sportu i u svezi sa sportom. To bi se moralo dogoditi putem zakonskih novela koje bi popunile sadašnje pravne praznine i nedorečenosti te uzrokovale nadopune odredbi nekih pravnih akata, prvenstveno Zakona o sportu. Sportski bi sudovi bili nadležni isključivo u svim sporovima vezanima za sport, osim u slučajevima kaznenih djela u sportu za koje je predviđena zatvorska kazna. Sastojali bi se od osoba pravne struke koje dobro poznaju stručne zakonitosti sporta i njegove specifičnosti kao ljudske aktivnosti, odnosno bivših sportaša pravne struke i ostalih osoba (npr. vještaka) koji su specijalisti za pojedine sportove. Ovakvi su slučajevi trenutno pod nadležnošću redovnih sudova, a takvo stanje dovodi do dugotrajnih sporova i parnica te visokih troškova involviranih aktera i države. Suci redovnih sudova (općinski i županijski) ne moraju poznavati sport i njegove specifičnosti i zakonitosti.
\end{abstract}

Ključne riječi: sportaši, sportski ugovor, sportske i pravne posljedice nestručnosti, specijalizirani sportski sud, Zakon o sportu, zakonske novele

\footnotetext{
${ }^{1}$ Mr. sc. Dean Vuleta, Gupčeva 6, 21000 Split, vuleta.dean@gmail.com
} 


\section{UVOD}

Sport predstavlja institucionaliziranu fizičku i natjecateljsku aktivnost kojom se involvirane osobe bave radi natjecanja i rekreacije. Pod sportom i sportskom djelatnošću općenito se misli na natjecatelje, sportska natjecanja, sportsku rekreaciju, sportsku poduku (koju provode treneri, sportski učitelji, razni sportski instruktori), te na ostale osobe (posredno involvirane u sport) kao što su menadžeri, sponzori, suci, organizatori sportskih natjecanja i sl. Sport i sportske djelatnosti i njihovi akteri, involvirani neposredno i posredno u sve aktivnosti u sportu i oko sporta, predstavljaju specifičnu globalnu djelatnost koja ima temeljni društveni značaj u svakom društvu. ${ }^{2}$ Sportsko pravo, putem zakonskih i podzakonskih propisa, regulira specifične pravne odnose nastale u sportu i oko sporta. Osnovni pravni akt kao Lex specialis u ovoj grani pravne znanosti jest Zakon o sportu (u daljnjem tekstu ZOS), NN 71/06, 150/08, 124/10, 124/11, 86/12, 94/13, 85/15, 19/16. ZOS u članku 5. određuje da sustav sporta u Republici Hrvatskoj čine fizičke osobe, pravne osobe i školska sportska društva koja se osnivaju bez pravne osobnosti. Fizičke osobe su sportaši, treneri, osobe osposobljene za rad u sportu, osobe koje sudjeluju u organiziranju i vođenju sportskog natjecanja (sportski sudac, sportski delegat, sportski povjerenik) i menadžeri u sportu. Pravne su osobe u sustavu sporta sportske udruge, sportska trgovačka društva i sportske ustanove. Činjenica je da je ZOS prepun pravnih praznina i da su pravne odredbe koje se tiču sporta (posredno sportaša, maloljetnih sportaša, trenera, menadžera, sponzora i ostalih osoba involviranih u sport) većim dijelom raspoređene u zakonskim i podzakonskim aktima drugih grana prava (prvenstveno radnog, obveznog i građanskog procesnog prava), a ne u okviru osnovnog pravnog akta (ZOS) što je pravno nedopustivo. ${ }^{3}$ Budućim zakonskim novelama i zakonodavnim nadopunama ZOS-a, taj pravni akt mora postati jedini izvor pravnog reguliranja odnosa u sportu i u svezi sa sportom.

\section{PRAVNE KARAKTERISTIKE KLASIFIKACIJE SPORTAŠA}

Sportski analitičari i djelomično odredbe ZOS-a određuju pojam profesionalnog sportaša i sportaša amatera te postavljaju jasnu granicu prema njima. Profesionalcima se smatraju sportaši - natjecatelji, treneri, tehničko-sportski direktori i druge osobe čije je jedino zanimanje tjelesno pripremanje sportaša odnosno priprema i organizacija sportskih natjecanja. Sportaši profesionalci moraju ispunjavati uvjete za takav status, a njih propisuje nacionalna sportska federacija svojim

2 Temeljni nacionalni dokument, Ustav Republike Hrvatske NN 56/90, 135/97, 8/98, 113/00, 124/00, 28/01, 41/01, 55/01, 76/10, 85/10, 05/14, u članku 69. utvrđuje da su tjelesna kultura i sport djelatnosti od posebnog društvenog značaja.

3 Osim Zakona o sportu, Zakon o radu, NN br. 149/09, 61/11, 82/12, 73/13, 93/14, 127/17, Zakon o obveznim odnosima, NN br. 35/03, 41/08, 125/11, 78/15, 29/18, Zakon o sudovima, NN br. 28/13, 33/15, $82 / 15,82 / 16$, Zakon o parničnom postupku, NN br. 53/91, 81/92, 58/93, 112/99, 88/01, 117/03, 88/05, 2/07, 47/08, 84/08, 123/08, 57/11, 148/11, 25/13, 89/14, te Međunarodni ugovori i Međunarodni akti koji obvezuju Republiku Hrvatsku. 
podzakonskim propisima. Tim propisima pravi se razlika između sportaša amatera i sportaša profesionalaca. Sportaši amateri bave se sportskom aktivnošću, koja im nije izvor životne egzistencije, radi rekreacije ili stjecanja sredstava za neke životne potrebe, a sportaši profesionalci bave se sportskom aktivnošću koja im je jedini izvor egzistencije. ${ }^{4}$ Veliki je propust zakonodavca što u članku 5. ZOS-a nije utvrdio i regulirao pravni status maloljetnih sportaša: mladih sportaša do 14 godina starosti, kadeta od 14 do 16 godina, te juniora od 16 do 18 godina. Postoje kvalitetni maloljetni sportaši državne i međunarodne kvalitete čiji roditelji, kao zakonski zastupnici, imaju sklopljene ugovore o sponzoriranju s raznoraznim menadžerima, sponzorima, sportskim klubovima i trenerima (npr. tenisači maloljetnici). Pravni odnosi maloljetnih sportaša i drugih aktera sportskih djelatnosti potpuno su neutvrđeni odredbama što je prilično nerazumljivo. ${ }^{5}$ Mnogi su maloljetni sportaši (osobe do navršenih 18 godina) aktivno uključeni u sustav sporta, ne samo kao amateri (rekreativci), nego i kao profesionalci pojedinci ili članovi sportskih udruga. Problematična pitanja maloljetnika u profesionalnom sportu predmet su pažnje i interesa teoretičara sportskog prava u nacionalnim i internacionalnim okvirima. Stoga je hitno potrebno zakonsko i podzakonsko utvrđivanje i reguliranje pojma maloljetničkog sporta kroz klasifikaciju maloljetnika po godištima. ${ }^{6}$ Maloljetnici su prilično eksponirani u svijetu sporta zbog svoje mladosti i dugoročne profitabilnosti. Općenito, maloljetnici su najugroženija skupina u društvu.

\section{UGOVOR KAO TEMELJNI SEGMENT PRAVNOG ODNOSA U SPORTU}

Posljedica neutvrđenosti sportskog ugovora u ZOS-u, kao temeljnog pravnog dokumenta sportskopravnih odnosa, pojava je raznoraznih sponzora i osoba sumnjive prošlosti koji u ovakvim neriješenim pravnim odnosima vide priliku za profit kroz plasman svog sumnjivo zarađenog novca. ${ }^{7}$ Ugovor kao temeljni segment pravnog odnosa u sportu i sportskim djelatnostima spominje se samo jednom rečenicom u članku 8., stavak 1 . ZOS-a. ${ }^{8}$ Općenito, u sportu se pojavljuju: 1. ugovor o profesionalnom igranju, 2. ugovor o igranju kao dodatnoj djelatnosti (amaterski

4 O relevatnim pojmovima u sportu vidi Hrvoje Kačer, „Uvod i osobe u športu“, u: (Uvod u) športsko pravo, Zagreb, 2009; str. 3.

5 O problematici sportskih ugovora maloljetnika vidi u Blanka Ivančić Kačer, „Športski ugovori maloljetnika, posebno s aspekta mjerodavnog prava“, Zbornik radova Pravnog fakulteta u Splitu, god. 47, 2/2010, str. 427-450.

6 Da bi se kvalitetno reguliralo pitanje maloljetnika u sportu, potrebno je prvenstveno postaviti i analizirati problem. O takvoj problematici Blanka Ivančić Kačer, op. cit. u bilj. 4., str. 435.

7 Sportski ugovori o profesionalnom igranju temelj su pravnih odnosa u sportu. Sportski ugovori mogu biti: ugovor o radu u sportu i ugovor o sportskopravnim odnosima. Radi se o ugovorima ,Sui generis“, jer su u njima pomiješani elementi ugovora o radu, ugovora o djelu i ugovora o nalogu. O tome Marko Ivkošić, (Uvod u) športsko pravo, Zagreb, 2009., str. 114.

8 Čl. 8. st. 1.ZOS-a. Sudjelovanje u sportskim natjecanjima smatra se profesionalnim ako sportaš koji sudjeluje u sportskim natjecanjima ima sklopljen ugovor o profesionalnom igranju ili ugovor sa sportskim klubom, ili ako sportaš obavlja samostalnu sportsku djelatnost sudjelovanja u sportskim natjecanjima. 
ugovor), 3. ugovor o sportskom usavršavanju i stipendiranju. Navedeni ugovori su po vrsti dvostranoobvezni, onerozni, komutativni, kauzalni, inter vivos i formalni pravni poslovi. Pravna posljedica nesklapanja navedenih ugovora u obveznoj pisanoj formi propisanoj po mjerodavnim podzakonskim aktima jest ništavnost takvihugovora. ${ }^{9}$ Zakonodavac bi, de lege ferenda, trebao normirati barem osnovne elemente ove specifične problematike kao okvirni temelj. Ukoliko se to ne napravi u bliskoj budućnosti, nakon popunjavanja zakonskih pravnih praznina, moglo bi doći do neusuglašenosti pravnih normi. ${ }^{10}$

U sportskoj praksi naročito su aktualni ugovori o pravnom odnosu između sportaša kao fizičke osobe i sportske udruge, te ugovori između sportaša i trenera, menadžera, sponzora i sl. Jedna od bitnih karakteristika ugovora, općenito, jest ostvarenje načela jednakosti stranaka u ugovoru (sit principium aequalitatis partium contramentium). Ovo načelo u sportskim ugovorima rijetko egzistira u sportskoj praksi, jer je uobičajeno da se pravni odnos stranaka ne temelji na ravnopravnom položaju. Sportaš na početku karijere, pogotovo maloljetnik i njegovi roditelji kao zakonski zastupnici svjesni su da je za njegov trening, daljnji rad i putovanja na sportska natjecanja potreban znatan financijski ulog, pa pristaju na uvjete koje nudi druga strana premda su oni dugoročno nepovoljni za njega. Kao primjer takvih ugovora mogu poslužiti sportski ugovori maloljetnih tenisača, odnosno njihovih roditelja kao zakonskih zastupnika, i raznoraznih menadžera, trenera i sponzora. Tenis se smatra jednim od najprofitabilnijih sportova za tenisače koji su željni brzog uspjeha i afirmacije i druge strane koja očekuje profit u kratkom vremenu nakon ulaganja.

Za vrijeme trajanja ugovora između profesionalnih sportaša i ostalih osoba (sportski klubovi, treneri, menadžeri, sponzori i drugi) involviranih u konkretni sportskopravni odnos postoje mnoga nerazjašnjena pitanja. Što je s pravima i obvezama sportaša i ostalih osoba po pitanju zdravstvene zaštite u pripremnom periodu za sportska natjecanja? ZOS u čl. 71. st. 1-4. jedini utvrđuje zdravstvenu zaštitu i određuje da se 6 mjeseci prije natjecanja osobi koja sudjeluje u sportskom natjecanju mora utvrditi opća zdravstvena sposobnost. Koje su disciplinske mjere u slučaju povrede radne discipline (sportaš odbija trenirati, a trener ne dolazi na posao)? Kako postupati u konkretnoj spornoj situaciji, nije utvrđeno zakonskim normama niti podzakonskim aktima. Radi se o nesavjesnom i nemarnom izvršavanju radne obveze i nepoštovanju propisane radne discipline. Sve su to pitanja koja je ZOS trebao normirati kroz potpuniju regulaciju sportskog ugovora kao temelja sportskopravnih odnosa. Specijalizirano sudsko tijelo jedino je koje bi se moglo nositi s ovom specifičnom problematikom, pa je zakonodavac dužan hitno svojim pravnim aktima oformiti takav sud i uvrstiti ga u postojeći pravosudni sustav.

9 Vidi Damir Jelušić, Vrste ugovora u hrvatskom sportskom pravu, str. 5-6.

10 Tu se misli na sukob pravnih normi zakonodavca, prvenstveno normi građanskog i radnog prava, $\mathrm{i}$ podzakonskih normi sportskih tijela. Vidi supra bilj. 6. Marko Ivkošić, (Uvod u) sportsko pravo, Zagreb, 2009. str. 114. 


\section{SUDSKO TIJELO NADLEŽNO ZA PRAVNO UTVRĐIVANJE, POGREŠNO DIJAGNOSTICIRANJE I SANKCIONIRANJE POSLJEDICA NEADEKVATNOG (NESTRUČNOG) RADA U SPORTU}

Sport kao posebna djelatnost, koja zauzima temeljno mjesto u svim civiliziranim društvima, zahtijeva aktivniju ulogu države kroz potpuniju pravnu regulaciju zakonskim i podzakonskim pravnim aktima. Novi specifični pravni odnosi u sportu, njihova problematika i mnogobrojni pravni sporovi i parnice vezani uz tu problematiku, dovode do potrebe uvođenja u pravni sustav i ustroja novih specijaliziranih (sportskih) sudova kao dijela sudbene vlasti. ${ }^{11} \mathrm{U}$ profesionalnom je sportu ostvarivanje profita „spiritus movens“ te djelatnosti i kad se poremeti to načelo, dolazi do spora među strankama ugovora. Redovni sudovi koji sude u sporovima vezanima uz sport i arbitražna sudišta (ako su ugovorena među strankama spora čime se derogira nadležnost redovnih sudova) ne mogu u potpunosti odgovoriti zahtjevima modernog vremena. Naime, suci redovnih sudova najčešće su osobe pravne struke koje nisu upućene u specifičnosti i zakonitosti sporta, dakle ne moraju biti sportski educirane, pa takvo činjenično stanje dovodi do dugotrajnih parnica i narušavanja načela pravičnosti i zakonitosti. Poznato je da karijera sportaša ima kratki vijek, pa dugotrajni (dugogodišnji) parnični postupci ne idu u prilog zainteresiranim strankama u sporu. Nikakvo pravo ni pravda ne mogu više nadoknaditi štetu koju će sigurno pretrpjeti svi akteri takvog spora, prvenstveno sportaši. Sudska praksa obiluje dugogodišnjim slučajevima sporova u sportu, a da im se još niti ne nazire konačno rješenje. Pogotovo je rješavanje takvih sporova komplicirano kad se odlučuje o pravnim posljedicama neadekvatnog treninga i metoda rada u profesionalnom sportu, pogrešnom dijagnosticiranju sportskih ozljeda od strane liječničke službe, te sankcijama za odgovorne osobe (pojava pretreniranosti i sportskih povreda - primarnih i sekundarnih). ${ }^{12}$ Ovakvi slučajevi nisu utvrđeni zakonskim ni podzakonskim aktima, mada su veoma česti u sportskoj praksi pa izazivaju dodatnu konfuziju među strankama spora i među sucima koji ne moraju biti sportski educirani.

Dakle, kad se uzme u obzir ubrzani razvoj sporta kao djelatnosti od posebnog društvenog interesa, sadašnji način vođenja sportskih sporova i općenito konfuzno stanje kod rješavanja posebno specifičnih sportskih sporova, onda je, de lege ferenda, optimalno rješenje ove kompleksne situacije uvođenje u pravni sustav, od strane zakonodavca, novih specijaliziranih sportskih sudova kao dijela sudbene vlasti. Uostalom, odredbe Zakona o sudovima daju pravni okvir za uvođenje novog

11 O specijaliziranom sportskom sudu i njegovu uvođenju u pravni sustav, Dean Vuleta, ,Sudska regulacija pravnih odnosa na području sportskog prava de lege ferenda, Zbornik Pravnog fakulteta $u$ Splitu, god. 52., 4/2015, str. 1144-1155.

12 Primarne su ozljede vidljive golom oku ili unutrašnje ozljede koje je lako dijagnosticirati (npr. lokomotornog sustava), a sekundarne povrede (povreda prava osobnosti, čl. 1100. ZOO-a) one su koje nastaju kao posljedica primarnih ozljeda (npr. depresija, gubitak samopouzdanja, strah zbog mogućeg prestanka bavljenja sportom i sl.). 
specijaliziranog suda, jer je zakonodavac svjestan da današnja vremena donose sve kompleksnije specifične odnose i sporove u moderni sport. ${ }^{13}$ Takvi bi sudovi morali biti sastavljeni od sportski educiranih sudaca, bivših sportaša pravne struke ili sportskih djelatnika pravne struke koji su posredno vezani uz sport, a ovlašteni su voditi sportski spor. Oni razumiju specifičnosti i zakonitosti sporta bolje od drugih, pa mogu voditi postupak u skladu s načelom pravičnosti (amiable compositeur ex aequo et bono), ekonomičnosti i suđenja u razumnom roku. ${ }^{14}$ Sportski sud, kao specijalizirani sud, trebao bi biti stvarno nadležan za rješavanje svih sporova u sportu i u svezi sa sportom između sportaša, fizičkih i pravnih osoba koje obavljaju sportsku djelatnost te sportskih udruga, ako zakonom nije određeno da za odlučivanje u određenoj vrsti takvih sporova postoji isključiva nadležnost redovnih sudova u Republici Hrvatskoj. Primjerice, kaznena djela počinjena u svezi sa sportom za koje je predviđena uvjetna ili bezuvjetna zatvorska kazna trebala bi ostati u nadležnosti redovnih sudova. Isto tako, specijalizirani sportski sud trebao bi biti stvarno nadležan za: pravno utvrđivanje, pogrešno dijagnosticiranje i sankcioniranje posljedica neadekvatnog (nestručnog) rada u sportu. Odredbe Zakona o sudovima i Zakona o parničnom postupku reguliraju nadležnost redovnih i specijaliziranih sudova kako ne bi dolazilo do sukoba nadležnosti. ${ }^{15}$

\subsection{Utvrđivanje pravnih posljedica neadekvatnog (nestručnog) rada u sportu}

U sportskoj praksi među sportašima i sportskim stručnjacima i analitičarima nije sporno koje su sportske posljedice neadekvatnog (nestručnog) rada u sportu. Svi se slažu da su to pojava pretreniranosti i sportske povrede (primarne - ozljede i sekundarne - povrede prava osobnosti) kao rezultat pretreniranosti. ${ }^{16}$ Međutim, sporno je koje su pravne posljedice takvih pojava, tko je odgovoran za njih i tko ih je dužan utvrditi i sankcionirati. Zakon o sportu i ostali zakoni čije se norme mogu posredno primijeniti na sport i sportskopravne odnose ne spominju takve slučajeve. S pravnog aspekta, trener kao najvažnija osoba u trenažnom procesu nije dovoljno kvalitetno utvrđena pravnim normama, jer o njegovoj stručnosti

13 Prema stavcima 1. i 2. čl. 14. Zakona o sudovima, NN br. 28/13, 33/15, 82/15, 82/16, u Republici Hrvatskoj sudbenu vlast obavljaju redovni (općinski, županijski) i specijalizirani sudovi (prekršajni, trgovački, upravni, Visoki prekršajni sud RH, Visoki trgovački sud RH, Visoki upravni sud RH), te Vrhovni sud RH. U skladu s odredbama čl. 14. st. 5. Zakona o sudovima, zakonom se mogu prema stvarnoj nadležnosti ili za određena pravna područja ustanovljavati i drugi redovni i specijalizirani sudovi.

14 Mada članci 63.-70. Zakona o sudovima utvrđuju suđenje u razumnom roku, svjedoci smo da sudska praksa obiluje dugogodišnjim postupcima koji prelaze svaku razumnu mjeru. Kao primjer može poslužiti spor teniskog kluba iz okolice Splita, s jedne strane, i maloljetne tenisačice odnosno njenih roditelja kao zakonskih zastupnika i ugledne njemačke agencije kao sponzora tenisačice. Spor traje od 1996. godine i ne vidi mu se kraja. Vrhovni Sud RH prihvatio je prijedlog za reviziju kojim se predmet vraća općinskom sudu na ponovno suđenje. O tome vidi, Dean Vuleta, op. cit. u bilj. 10., str. 1147.

15 Zakon o sudovima regulira nadležnost redovnih i specijaliziranih sudova čl. 17.-26., a ZPP regulira stvarnu nadležnost redovnih i specijaliziranih sudova čl. 33.-35.

16 Vidi supra bilj. br. 11. 
(određeni dokumenti koji dokazuju njegovu stručnost ili barem uspješni rezultati na natjecanjima) ovisi ostvarenje cilja trenažnog procesa - sportašev napredak kao osobe i natjecatelja. Da bi se taj napredak ostvario, potrebna je zakonodavna regulativa: u slučaju ugovora sportaša i ostalih osoba involviranih u konkretni sportskopravni odnos, adekvatnog trenerskog tretmana, odnosno s kime ce i na koji način trenirati i tko je ovlašten odabrati trenera. ${ }^{17}$ Koje su pravne posljedice na sklopljeni ugovor između sportaša i ostalih osoba u slučaju spora, odnosno ukoliko te osobe ne osiguraju adekvatnu kontrolu trenažnog procesa? ${ }^{18}$ Koje su pravne posljedice (sankcije) treneru koji neposredno rukovodi trenažnim procesom, a svojim je nestručnim radom sportašu s kojim trenira prouzročio fizičke i psihičke traume, čak i smrt? Koje su pravne posljedice prema menadžerima, sponzorima i ostalim osobama involviranima u konkretni sportskopravni odnos u slučaju pritiska usmjerenog na trenera i sportaša radi postizanja boljeg rezultata na natjecanjima, a što dovodi do prekomjernog fizičkog opterećenja sportaša? U stručnim krugovima u sportu poznato je da pojačana fizička aktivnost može dovesti do teških zdrastvenih tegoba: pretreniranosti, sportskih povreda, pa čak i do smrti. ${ }^{19}$ Sva ova pitanja trebaju biti pod nadležnošću specijaliziranog (sportskog) suda kad se izvrši nadopuna normi Zakona o sportu.

\subsubsection{Pravni pojam pretreniranosti u sportu}

U modernom profesionalnom i amaterskom sportu često dolazi do neželjenih posljedica radi prevelike želje za postizanjem sportskog uspjeha. Jedna je od njih i pretreniranost. Preteniranost je stanje sniženih funkcija organizma radi prekomjerne i neadekvatno dozirane fizičke aktivnosti, a dovodi do nemogućnosti obavljanja treninga određenog po uputama stručnog osoblja koje rukovodi trenažnim procesom. Pored želje za brzim napretkom samog sportaša, iscrpljivanjem svojih fizičkih resursa, jedan od najčešćih razloga koji dovode do pretereniranosti jest nestručnost sportskog trenera koji svoje neznanje želi prikriti pritiskom i prevelikim fizičkim opterećenjem sportaša čije tijelo (muskulatura) ne može podnijeti toliki fizički napor. U vrhunskom sportu postoje i dodatni razlozi za pretreniranost (loša prehrana i neadekvatan unos tekućine) koji dodatno slabe tijelo i onemogućavaju razmjerno odvijanje trenažnog procesa i faze oporavka (odmora) nakon fizičkog opterećenja. Sve ove pojave dovode i do psiholoških problema (gubitak samopouzdanja i

17 Prema čl. 9. ZOS-a, trener je definiran kao osoba koja planira i provodi sportsku pripremu, sportsku rekreaciju i sportsku poduku.

18 Tu se prvenstveno misli na trenere (stručnjake) koji ne sudjeluju neposredno u trenažnom procesu, već posredno kontroliraju kvantitetu i kvalitetu metoda rada, davajući raznorazne smjernice u trenažnom procesu treneru koji neposredno rukovodi trenažnim procesom. U posrednu kontrolu mogu biti uključeni i stručnjaci za pojedine grane sporta.

19 Poznat je slučaj nogometaša Marsonije Bruna Bobana (26) koji se dogodio 24. ožujka 2018. Preminuo je na terenu tijekom prvenstvene utakmice Treće hrvatske nogometne lige Istok u Slavonskom Brodu između NK Marsonije i NK Slavonije iz Požege zbog zatajenja srca. Obdukcijom nije otkriven medicinski razlog smrti, pa kao jedan od razloga to može biti neadekvatan (prenaporan) trenažni proces koji je doveo do poremećaja u krvožilnom sustavu, pogotovo kad se zna da je trenažni proces nogometaša izuzetno naporan i zahtjevan. 
kontrole nad vlastitim životom), a u nekim slučajevima i prestankom bavljenja određenim sportom. ${ }^{20}$ Kolika je trenerova pravna odgovornost za takve slučajeve i koja je za to pravna sankcija, tko je dužan to utvrditi u slučaju spora, tek treba utvrditi zakonskim i podzakonskim aktima. I ostale osobe involvirane u konkretni sportskopravni odnos (npr. menadžeri i sponzori) mogu biti pravno odgovorne, ako radi brzog ostvarenja svoga profita vrše pritisak na trenera da dodatno fizički opterećuje sportaša što dovodi do pojave pretreniranosti. Ovakve su pojave vrlo česte u sportu kao djelatnosti od posebnog društvenog značaja i potrebno ih je hitno utvrditi pravnim aktima te odrediti nadležnost suda. ${ }^{21}$

\subsubsection{Pravni pojam povrede u sportu}

Pretreniranost predstavlja veliku opasnost za sportaša jer tijelo onda postaje osjetljivije na sportske ozljede i prateće moguće pojave tih ozljeda - povrede osobnosti. U današnjem suvremenom sportu pred sportaše se postavljaju sve veći zahtjevi (uspješnost rezultata na natjecanjima), pa je i izloženost sportskim povredama sve veća. Da bi se učestalost sportskih povreda smanjila, od velikog je značaja i preventivni postupak da do povreda ne dođe i postupak oporavka neposredno nakon što je medicinsko osoblje povredu utvrdilo. Liječnici specijalisti su ti koji moraju utvrditi sportsku povredu i odrediti postupak i način oporavka (liječenje). Međutim, u sportskoj su praksi mogući, pa i dosta česti, slučajevi pogrešnog dijagnosticiranja sportskih povreda (primarnih ozljeda i mogućih sekundarnih povreda osobnosti koje prate primarne ozljede), od strane liječnika, a to onda dovodi i do pogrešno određenog postupka oporavljanja. Liječenje sportskih povreda specifično je, s glavnim ciljem potpunog izlječenja sportaša, s cjelovitim oporavkom, jer se inače riskira ponovno povređivanje koje je obično teže od prethodnog. ${ }^{22}$ Zakonodavnim novelama (ili barem podzakonskim aktima) treba potpunije utvrditi sankcije za liječničke pogreške. Ove povrede po svojoj su prirodi najčešće lake ozljede s kojima sportaši nastavljaju s redovitim trenažnim procesom, ali mogu prouzročiti smanjenu natjecateljsku sposobnost sportaša (zbog pojave sekundarnih povreda - prava osobnosti). Sportaš je prisiljen, na kraće ili dulje vrijeme, apstinirati od sportskih natjecanja, što za njega kratkoročno predstavlja dodatne probleme u vidu smanjenih financijskih prihoda, a dugoročno i opasnost od gubitka karijere. Lakše sportske ozljede, za koje je potrebno kratko vrijeme oporavka (do nekoliko dana), liječe se uz konzervativnu terapiju, a teže ozljede zahtijevaju invazivniji postupak liječenja, čak i operativni zahvat. Sekundarne povrede (prava osobnosti) zahtijevaju poseban postupak oporavka uz pomoć liječnika specijalista za to područje medicine.

20 O sindromu pretreniranosti vidi, Renata Barić, „Pretreniranost - da li ju prepoznajemo?“, Kineziološki fakultet Zagreb, i Franja Fratrić, ,Teorija i metodika sportskog treninga“.

21 Nadležan može biti jedino sportski sud kao specijalizirano sudsko tijelo. Vidi supra naslov 4.

22 Tu se prvenstveno misli na primarne ozljede nastale na treningu ili natjecanju i sekundarne povrede osobnosti nastale kao rezultat primarnih ozljeda. Vidi supra bilj. br. 11. 


\subsection{Utvrđivanje i pravni aspekt pogrešnog dijagnosticiranja sportskih povreda}

Na žalost, općepoznata je činjenica da se na mnogim amaterskim natjecanjima (lokalnog i regionalnog ranga) u sastavu liječničke ekipe, koja bi trebala brinuti za zdravstvenu sigurnost sportaša za vrijeme konkretnog natjecanja, nalazi samo liječnik pojedinac. On može, ali i ne mora biti specijalist za ozljede lokomotornog sustava, mišića i kostiju (ortoped) koje su očekivane i mogu se dogoditi za vrijeme natjecanja. Postoje slučajevi kad je službeni liječnik na natjecanju bio kardiolog (specijalist za srce i krvožilni sustav) ili liječnik opće prakse. U takvim situacijama u slučaju ozljeđivanja sportaša moguće su pogreške u dijagnosticiranju, a time i u postupku oporavka. Na natjecanjima državnog i međunarodnog ranga obično postoji liječnička ekipa sastavljena od nekoliko liječnika specijalista različitih grana medicine, pa je i mogućnost pogrešnog dijagnosticiranja manja. Međutim, u sportskoj praksi izvan natjecanja (u procesu treniranja) mogući su i postoje slučajevi pogrešnog dijagnosticiranja od strane liječnika specijalista (ortoped) za to područje medicine - primarnih sportskih ozljeda što može dovesti i do pogrešnog dijagnosticiranja sekundarnih sportskih povreda (prava osobnosti), nastalih kao rezultat primarnih ozljeda. Postavlja se logično pitanje koje su pravne sankcije za takve liječnike, pogotovo ako se radi o brzopletom i nemarnom postavljanju dijagnoze koje nije u skladu s načelom lege artis (po pravilima struke). ${ }^{23}$ Koje pravne mogućnosti imaju sportaši na raspolaganju kako bi se zaštitili od liječničkih pogrešaka? ${ }^{24}$ Ova i slična pitanja treba utvrditi ZOS te mogu i moraju biti jedino pod nadležnošću specijaliziranog sportskog suda.

23 Postoji slučaj poznatog splitskog tenisača iz 2016. godine kojem je liječnik, ortoped međunarodnog renomea, postavio pogrešnu dijagnozu zbog koje je sportaš u zadnji trenutak izbjegao sepsu te amputaciju noge i jedva spasio sportsku karijeru. Srećom, zahvaljujući svojoj upornosti, sportskom iskustvu i svakodnevnom treningu, sportaš je uspješno nastavio karijeru iako su mu svi eminentni liječnici, ortopedi, zabranili svaku fizičku aktivnost. Naime, radi se o tome da je sportaš na treningu prilikom pada slomio bedrenu kost lijeve noge, a liječnik nemarnom analizom snimke utvrdio da se radi o lakšoj ozljedi istegnuća mišića s kojom se može normalno trenirati. Sportaš je uz velike bolove nastavio s treningom do trenutka kad više nije mogao trpjeti bolove i na ponovljenoj analizi snimke taj je isti liječnik utvrdio prijelom bedrene kosti lijeve noge te odredio potrebu hitne operacije, u roku od tri dana, jer postoji opasnost od sepse i amputacije noge. Nakon operacije nekoliko uglednih kolega liječnika ortopeda, kao i liječnik koji je dao pogrešnu dijagnozu i obavio operaciju, dali su svoju prognozu o nastavku daljnje sportske karijere tenisača i svi redom potvrdili da za to nema nikakve šanse. Pored toga zabranili su mu svaku fizičku aktivnost. Međutim, sportaš, koji je imao veliko sportsko iskustvo i nije poslušao njihovu sugestiju nego je samoinicijativno radio na jačanju muskulature, potpuno se oporavio i danas ponovno uspješno izvršava svoje sportske obveze. Da je poslušao liječničku sugestiju, ostao bi slabo pokretan i bez sportske karijere.

24 Zakon o zaštiti prava pacijenata NN.br.169/04, 37/08 glava 2. Prava pacijenata - pravo na suodlučivanje, čl. 6. i 16. Pravo na suodlučivanje obuhvaća pravo pacijenta na obaviještenost i pravo na prihvaćanje ili odbijanje pojedinog dijagnostičkog, odnosno terapijskog postupka. 


\subsection{Pravno sankcioniranje odgovornih osoba za posljedice neadekvatnog (nestručnog) rada u sportu}

Odgovorne osobe za posljedice neadekvatnog rada (treninga) u sportu mogu biti: 1. treneri koji neposredno rukovode trenažnim procesom i čija je nestručnost $u$ radu dovela sportaša do sportskih posljedica (primarnih ozljeda i mogućih povreda osobnosti), 2. menadžeri i sponzori involvirani u konkretni sportskopravni odnos koji su svojim pritiskom i raznim ucjenama prisilili trenera da svoga sportaša izlaže prekomjernim fizičkim naporima, što dovodi do neželjenih sportskih posljedica. Sve se to radi sa svrhom postizanja što boljih rezultata na natjecanjima, a radi ostvarenja profita kao spiritus movensa sportske djelatnosti. Odgovorni mogu biti i 3. liječnici koji su svojim pogrešnim dijagnosticiranjem primarnih ozljeda i sekundarnih povreda osobnosti doveli sportaša u nezavidan položaj. ${ }^{25}$ Ove osobe u pravilu su odgovorne za imovinsku i neimovinsku štetu počinjenu sportašu. Isto tako, odgovorni mogu biti i sportaši u konkretnom pravnom odnosu koji svoje probleme duguju samoozljeđivanju i neprihvaćanju sugestija stručnog osoblja. Nakon popunjavanja pravnih praznina ZOS-a, specijalizirani sportski sud mora utvrditi koja je osoba pravno odgovorna u svakom konkretnom slučaju i odrediti joj sankciju. Do nadopuna odredbi ZOS-a, redovni sudovi nadležni su suditi u ovim kompleksnim parnicama, prvenstveno po odredbama Zakona o obveznim odnosima, Zakona o radu i dijelom po odredbama Zakona o parničnom postupku. Te odredbe ne utvrđuju konkretnu odgovornu osobu iz sportskopravnog odnosa (sa svim svojim specifičnostima trenera, liječnika, menadžera, sponzora i sportaša), već samo odgovornu osobu (štetnika) i oštećenika, a ne sportaša kao oštećenu osobu. Isto tako, spominje se radni odnos, radnik i poslodavac, a ne sportskopravni odnos, sportaš te sportski trener, menadžer i sponzor.

\section{ZAKONSKE NOVELE KAO REZULTAT PRAVNOG REGULIRANJA NEKIH NEUTVRĐENIH POJMOVA U SPORTU}

Novi ZOS kao lex specialis, umjesto trenutno važećeg ZOS-a prepunog pravnih praznina, trebalo bi de lege ferenda nadopuniti putem zakonskih novela. Takva nadopuna mora se izvršiti upotrebom postojećih odredbi ZOS-a i nekim novim odredbama koje bi upotpunile neutvrđene pojmove. Isto tako, u nadopuni se treba koristiti postojećim i novim odredbama nekih zakona, koje moraju biti

25 Kao primjer konkretne sankcije može poslužiti slučaj pogrešne liječničke dijagnoze. U jednom slučaju kod nas sud je stradaloj studentici medicine četvrte godine zbog pogrešne liječničke dijagnoze dosudio rentu do 65. godine života u visini plaće liječnika specijalista jer se pretpostavljalo da bi studentica došla do tog stupnja obrazovanja. Vrhovni sud je 2002. godine donio orijentacijske kriterije za utvrđivanje visine neimovinske štete kojih se sudovi u pravilu pridržavaju. Primjerice, utvrđuje se da je za fizičke boli naknada po danu od 70 do 370 kuna, za strah od 2200 do 30.000 kuna. Naknada za duševne boli (povrede prava osobnosti) zbog smanjenja životne aktivnosti (kada netko više ne može voziti automobil, baviti se sportom ili svojim zanimanjem) ovisi o težini povrede i okolnostima slučaja. O ovome vidi www. osiguranje.hr/Tisak. 
utvrđene de lege ferenda, s obzirom na nove pravne odnose u sportu i promijenjenu sportskopravnu terminologiju prilagođenu specifičnostima sportskopravnih odnosa i svakom pojedinačnom slučaju. Prvenstveno se misli na Zakon o sudovima, Zakon o parničnom postupku i Zakon o radu, a neke od postojećih odredbi Zakona o obveznim odnosima treba utvrditi prema sportskopravnoj terminologiji i primijeniti ih u novom ZOS-u. ${ }^{26}$ Takvi su terminološki izrazi: 1. sportaš (umjesto radnik), 2. sportska udruga, trener, menadžer i sponzor (umjesto poslodavac), 3. sportskopravni odnos (umjesto radni odnos), 4. sportski ugovor (umjesto ugovor o radu). Ovoj specifičnoj terminologiji treba nadodati i termine: 5. odgovorna osoba (štetnik), 6. oštećenik i 7. Sportski sud. U pravilu, oštećenik je sportaš, a štetnik može biti liječnik (koji je dao sportašu pogrešnu dijagnozu sportske povrede), sportska udruga, trener, menadžer i sponzor, ovisno o tome koliko su u konkretnom slučaju pridonijeli neadekvatnom radu koji je uzrok sportaševih sportskih i zdrastvenih tegoba. Isto tako, štetnici mogu biti sportska udruga, trener, menadžer i sponzor ako ne izvršavaju ostale obveze prema sportašu (npr. neizvršavanje financijskih obveza prema sportašu za njegov rad). U posebnim konkretnim slučajevima štetnik može biti i sportaš, a ostale osobe oštećenici (npr. kad sportaš odbija svoju obvezu treniranja bez nekog opravdanog razloga ili ako je sportaš poslodavac treneru ili menadžeru pa ne izvršava svoje novčane obveze). ${ }^{27}$

Uvođenje specijaliziranog sportskog suda u pravosudni sustav s ovlastima utvrđivanja činjenica i suđenja u postojećim i novonastalim pravnim odnosima u sportu i u svezi sa sportom dovelo bi, de lege ferenda, do potrebe za nadopunom odredbi nekih zakona putem zakonskih novela, prvenstveno ZOS-a. Zakon o sudovima i Zakon o parničnom postupku, de lege ferenda, treba nadopuniti nekim manjim korekcijama time što bi se nekim postojećim odredbama o sudovima i suđenju u parničnom postupku nadodala sintagma Sportski sudovi i time bi došlo do promjena nekih odredbi. Zakon o sportu, de lege ferenda, treba nadopuniti odredbama koje reguliraju neke važne sportskopravne odnose kao što su: radni odnosi u sportu (sportski ugovori - ugovori o radu u sportu i ugovori o sportskopravnim odnosima), pravne sankcije iz sportskih ugovora te funkciju i nadležnost Sportskog suda, s krajnjim ciljem reguliranja svih pravnih odnosa u sportu ili u svezi sa sportom.

\subsection{Zakon o sudovima}

\section{Članak 3.}

(2) Sudovi odlučuju u sporovima o temeljnim pravima i obvezama čovjeka, o pravima i obvezama Republike Hrvatske i jedinica lokalne i područne (regionalne) samouprave te o pravima i obvezama drugih pravnih osoba, izriču kazne i druge mjere počiniteljima kaznenih djela i prekršaja utvrđenih zakonom i drugim propisima, odlučuju o zakonitosti općih i

26 Vidi infra bilješku br. 28.

27 Novu bi promijenjenu terminologiju od 1.-4. nadopunjeni ZOS trebao preuzeti po uzoru na odredbe iz Zakona o radu, a izraze 5. i 6. Iz Zakona o obveznim odnosima. Izraz Sportski sud predstavlja nadopunu nekim odredbama Zakona o sudovima i Zakona o parničnom postupku. 
pojedinačnih akata javnopravnih tijela, rješavaju sporove o osobnim odnosima građana, radne, trgovačke, imovinske, sportske i druge građanskopravne sporove te odlučuju o drugim pravnim stvarima kad je to zakonom određeno. ${ }^{28}$

\section{Članak 14.}

(3) Specijalizirani sudovi su trgovački sudovi, upravni sudovi, prekršajni sudovi, sportski sudovi, Visoki trgovački sud RH, Visoki upravni sud RH, Visoki prekršajni sud RH i Visoki Sportski sud RH.

\section{Članak 15.}

(2) Županijski, trgovački, upravni i sportski sudovi ustanovljavaju se za područje jedne ili više županija.

(3) Visoki trgovački sud RH, Visoki upravni sud RH, Visoki prekršajni sud RH i Visoki Sportski sud RH ustanovljavaju se za područje RH sa sjedištem u Zagrebu.

\section{Članak 16.}

(2) Općinski, županijski, trgovački, upravni, prekršajni i sportski sudovi mogu iznimno obavljati sudbenu vlast i izvan sjedišta suda, u određene sudbene dane ili osnivanjem stalnih službi ili odjela.

\section{Članak 21.a (novi članak)}

Pored nadležnosti propisane drugim zakonima, sportski sudovi:

1. sude u prvom stupnju u sporovima iz sportskoga ugovora o ili u sporovima u svezi sa sportom, osim ako za vođenje takvog postupka nije propisana stvarna nadležnost drugog tijela,

2. provode postupak za pravno utvrđivanje, pogrešno dijagnosticiranje i sankcioniranje posljedica neadekvatnog (nestručnog) rada u sportu,

3. provode postupak za pravno utvrđivanje i nadoknadu imovinske i neimovinske štete (prava osobnosti), odgovorne osobe - štetnika prema oštećenoj osobi - oštećeniku iz točke 1. i 2. ovoga članka, ${ }^{29}$

4. postupaju u registarskim stvarima fizičkih i pravnih osoba u svezi sa sportom,

5. odlučuju o upisima sportskih udruga u registar sportskih udruga,

6. odlučuju o prijedlozima u svezi s osnivanjem, radom i prestankom sportske udruge,

28 Podebljani termini (izrazi) jesu prijedlozi de lege ferenda.

29 U ovom slučaju treba primijeniti sljedeće odredbe ZOO-a, prilagođene sportskopravnoj terminologiji: GLAVA IX. IZVANUGOVORNI OBVEZNI ODNOSI, odjeljak 1. Prouzročenje štete, odsjek 1. Opća načela pretpostavke odgovornosti, čl. 1045. - 1046., čl. 1051., čl. 1054 ., odsjek 7. Popravljanje štete, 1. popravljanje imovinske štete, čl. 1085. - 1092., čl. 1095. - 1097., 5. popravljanje neimovinske štete, čl. 1100. - 1104., čl. 1107., čl. 1110. 
7. odlučuju o prijedlozima za otvaranje stečajnog postupka i provode stečajne postupke sportskih udruga,

8. provode postupak priznanja inozemnih sudskih odluka, kao i arbitražnih odluka u sportskim sporovima,

9. provode osiguranje dokaza iz područja svoje nadležnosti,

10. obavljaju i druge poslove određene zakonom.

$$
\text { Članak 26.a (novi članak) }
$$

Visoki Sportski sud Republike Hrvatske:

1. odlučuje o žalbama protiv odluka koje su u prvom stupnju donijeli sportski sudovi,

2. rješava sukob mjesne nadležnosti između sportskih sudova te odlučuje o delegaciji nadležnosti između sportskih sudova,

3. obavlja druge poslove određene zakonom.

\section{Članak 36.}

(2) Za tajnika Vrhovnog suda RH, Visokog trgovačkog suda RH, Visokog upravnog suda RH, Visokog prekršajnog suda RH i Visokoga Sportskoga suda RH može biti primljena osoba koja ispunjava uvjete za višeg sudskog savjetnika u tom sudu.

\section{Članak 38.}

(2) Na sjednicama sudskih odjela županijskih sudova, Visokog trgovačkog suda RH, Visokog upravnog suda RH, Visokog prekršajnog suda RH i Visokoga Sportskoga suda RH razmatraju se i pitanja od zajedničkog interesa za sudove nižeg stupnja s područja tih sudova.

\section{Članak 40.}

(2) Pravno shvaćanje prihvaćeno na sjednici svih sudova odnosno sudskog odjela Vrhovnoga suda RH, Visokoga trgovačkoga suda RH, Visokoga upravnoga suda RH, Visokoga prekršajnoga suda RH, Visokoga Sportskoga suda RH i na sjednici odjela županijskog suda obvezno je za sva drugostupanjska vijeća ili suce pojedince tog odjela odnosno suda.

\section{Članak 43.}

(2) Građanski odjel obuhvaća područja građanskog, trgovačkog, upravnog i sportskog prava.

\section{Članak 50.}

(2) Za trgovačke sudove osniva se sudačko vijeće pri Visokom trgovačkom sudu RH, za upravne sudove pri Visokom upravnom sudu RH, za prekršajne sudove pri Visokom prekršajnom sudu RH, a za sportske sudove pri Visokome sportskome sudu RH. 


\begin{abstract}
Članak 51.
(6) (novi stavak) Sudačko vijeće sportskih sudova ima 15 članova, od kojih je devet članova iz redova Visokoga sportskoga suda $\mathrm{RH}$, a šest iz reda sudaca sportskih sudova.

(7) U odlučivanju o poslovima sudačkog vijeća koji se odnose na suce županijskih sudova, Visokoga trgovačkoga suda RH, Visokoga upravnoga suda RH, Visokoga prekršajnoga suda RH i Visokoga sportskoga suda RH sudjeluju samo članovi sudačkog vijeća iz reda sudaca tih sudova.
\end{abstract}

Bivši stavak (6) postaje stavak (8).

\title{
Članak 53.
}

(2) Članove sudačkih vijeća trgovačkih, upravnih, prekršajnih i sportskih sudova iz reda sudaca Visokoga trgovačkoga suda RH, Visokoga upravnoga suda RH, Visokoga prekršajnoga suda RH i Visokoga sportskoga suda RH biraju suci tih sudova, a članove iz reda sudaca trgovačkih, upravnih, prekršajnih i sportskih sudova suci tih sudova.

(3) Općinski sud, trgovački sud, upravni sud, prekršajni sud i sportski sud ne mogu u sudačkom vijeću imati više od tri člana iz reda sudaca istoga suda.

\section{Članak 68.}

(2) Ako se zahtjev odnosi na postupak koji je u tijeku pred Visokim trgovačkim sudom RH, Visokim upravnim sudom RH, Visokim prekršajnim sudom RH ili Visokim sportskim sudom RH, o zahtjevu odlučuje Vrhovni sud RH.

\section{Članak 96.}

(2) U postupku napredovanja suca za suca županijskog suda, Visokoga trgovačkoga suda RH, Visokog upravnoga suda RH, Visokoga prekršajnoga suda RH i Visokoga sportskoga suda RH ocjenjuje se rad suca u razdoblju od posljednjih pet godina u kojem je sudac obnašao sudačku dužnost, a za suca Vrhovnog suda RH rad suca u razdoblju od posljednjih deset godina.

\section{Članak 110.}

(4) Sudski savjetnici odnosno viši sudski savjetnici ovlašteni su na provođenje postupka i predlaganje nacrta odluka u smislu stavaka 1. i 2. ovoga članka.

1. U parničnim postupcima u sporovima za isplatu novčane tražbine ili naknadu štete u kojima vrijednost predmeta spora ne prelazi 100.000,00 te u trgovačkim i sportskim sporovima u kojima vrijednost predmeta spora ne prelazi 500.000,00 kuna.

\section{Članak 126.}

(7) Županijski, trgovački i sportski sudovi vode popis stalnih sudskih vještaka imenovanih za njihovo područje. 


\subsection{Zakon o parničnom postupku}

\section{Članak 1.}

Ovim se zakonom uređuju pravila postupka na temelju kojih sud raspravlja i odlučuje u sporovima o osnovnim pravima i obvezama čovjeka i građanina, o osobnim i obiteljskim odnosima građana te u radnim, trgovačkim, imovinskim, sportskim i drugim građanskopravnim odnosima, ako zakonom nije za neke od tih sporova određeno da u njima sud rješava po pravilima kojega drugog postupka.

\section{Članak 34.d (novi članak)}

Sportski sudovi u parničnom postupku u prvom stupnju sude:

1. U sporovima iz sportskih ugovora koji nastaju neposredno ili posredno u svezi sa sportom između pravnih osoba, fizičkih i pravnih osoba uključujući i sporove između fizičkih osoba, osim ako nije riječ o sporovima u kojima prema zakonu uvijek sude općinski sudovi, odnosno ako nije riječ o sporovima za koje je zakonom određena nadležnost nekog drugog suda.

2. U sporovima u povodu osnivanja, rada i prestanka pravne osobe u sportu.

3. U sporovima između članova pravne osobe u sportu međusobno te između članova pravne osobe u sportu i drugih osoba.

4. U sporovima o odgovornosti člana pravne osobe u sportu, člana uprave ili nadzornog odbora za obveze te osobe.

Bivši članak 34. d postaje članak 34. f

\section{Članak 34. e (novi članak)}

Visoki sportski sud RH u parničnom postupku:

1. sudi u prvom stupnju u slučajevima predviđenima zakonom,

2. odlučuje o žalbama protiv odluka sportskih sudova donesenih u prvom stupnju,

3. obavlja druge poslove određene zakonom.

\section{Članak 34. $\mathrm{f}$}

Vrhovni sud RH u parničnom postupku:

1. odlučuje o žalbama prvostupanjskih odluka županijskih sudova, Visokoga trgovačkoga suda RH i Visokoga sportskoga suda RH i protiv vlastitih prvostupanjskih ako zakonom nije drugačije određeno.

GLAVA DVADESET I SEDMA Postupak u u parnici iz radnog i sportskopravnog odnosa

U člancima 433.-435. uz sintagmu radnih odnosa dodati i sportskopravnih odnosa.

GLAVA TRIDESET I DRUGA Postupak pred Trgovačkim i Sportskim sudovima

U člancima 488., 489., 492.a ,492.b, 497.a, 499.-502. uz sintagmu pred Trgovačkim dodati i Sportskim sudovima. 


\subsection{Zakon o radu}

\section{Članak 1.}

Ovim se Zakonom uređuju radni i sportskopravni radni odnosi u Republici Hrvatskoj, ako drugim zakonom ili međunarodnim ugovorom, koji je sklopljen i potvrđen u skladu s Ustavom RH, te objavljen, a koji je na snazi, nije drukčije određeno. ${ }^{30}$

\section{Članak 4.}

(1) Radnik zaposlenik, uposlenik, djelatnik, sportaš te ostale fizičke osobe u sustavu sporta su, u smislu ovoga Zakona, fizičke osobe koje u radnom ili sportskopravnom radnom odnosu obavljaju određene poslove za poslodavca.

(2) Poslodavac iz radnog ili sportskopravnog radnog odnosa je, u smislu ovoga Zakona, fizička ili pravna osoba koja zapošljava radnika ili ostale fizičke osobe u sustavu sporta i za koju radnik u radnom ili sportskopravnom radnom odnosu obavlja određene poslove.

(3) (novi stavak) Poslodavac iz sportskopravnog radnog odnosa u smislu članka 2. ovoga Zakona je fizička ili pravna osoba koja zapošljava sportaša, trenera ili menadžera i za koju te osobe po sportskom ugovoru obavljaju određene poslove.

(4) (novi stavak) Poslodavac može biti i sportaš koji kao fizička osoba zapošljava druge fizičke osobe, trenera ili menadžera, da na temelju sportskog ugovora obavljaju određene poslove za njega.

Bivši stavci 3. i 4. postaju stavci 5 . i 6.

U svim člancima Zakona o radu, Zakonodavac može, pored postojećih termina radnik, poslodavac i ugovor o radu, pridodati termine - sportaš te ostale osobe u sustavu sporta, poslodavac iz sportskopravnih odnosa i sportski ugovor, ako se oni, s obzirom na specifičnosti sportskopravnih odnosa, uklapaju odnosno podudaraju s postojećim terminima.

\subsection{Zakon o sportu}

\section{SUSTAV SPORTA I SPORTSKE DJELATNOSTI}

\section{Osobe u sustavu sporta}

\section{Članak 5.}

(2) Fizičke osobe u sustavu sporta jesu:

- sportaši,

- sportaši maloljetnici,

- treneri,

30 Radni i sportskopravni radni odnosi su širi pojam i obuhvaćaju sve pravne odnose u svezi s radom i radom u sportu, za razliku od ugovora o radu i ugovora o radu u sportu koji se odnose na konkretne pravne slučajeve. 
- osobe osposobljene za rad u sportu,

- osobe koje sudjeluju u organiziranju i vođenju sportskog natjecanja (sportski sudac, sportski delegat i sportski povjerenik) i

- menadžeri u sportu.

\section{Članak 7.}

(stavak 6) (novi stavak) U slučaju spora između sportaša i ostalih osoba involviranih u konkretni pravni odnos, Sportski sud je nadležan utvrditi okolnosti i činjenice slučaja koji je doveo do spora te provoditi ostale pravne radnje koje dovode do sankcije odgovornoj osobi.

\section{Sportaš maloljetnik \\ Članak 7.a (novi članak)}

(1) Sportaš maloljetnik, u smislu ovoga Zakona, malodobna je osoba do 18 godina starosti, koja se priprema i sudjeluje u sportskim natjecanjima:

- kao član pravne osobe koja obavlja sportsku djelatnost sudjelovanja u sportskim natjecanjima, uz nadzor roditelja kao zakonskih zastupnika;

- kao osoba koja obavlja samostalnu sportsku djelatnost sudjelovanja u sportskim natjecanjima. Sportaš maloljetnik može ulaziti u sve vrste pravnih odnosa koje odobre njegovi roditelji kao zakonski zastupnici.

(2) Sportaš maloljetnik je:

1. mladi sportaš do 14 godina starosti,

2. kadet 14 - 16 godina starosti,

3. junior 16 - 18 godina starosti.

(3) U svim slučajevima u kojima se kao akter pojavljuje sportaš maloljetnik primjenjivat će se odredbe članaka 6., 7., 7a., (novi članak), 8. i 12a., s time da se posebno naglašava da za sportaša maloljetnika, u njegovo ime i za njegov račun, ugovore sklapaju roditelji kao njegovi zakonski zastupnici.

\section{Članak 8.}

Brisan stavak 3. (Status profesionalnog sportaša kao i njegova prava i obveze uređuju se aktima nacionalnoga sportskog saveza). ${ }^{31}$

\section{Trener}

Članak 9.

(stavak 6) (novi stavak) Pravna ili fizička osoba koja po svom slobodnom izboru zapošljava trenera dužna je s njim sklopiti sportski ugovor o radu na određeno ili neodređeno vrijeme, ugovor o djelu ili ugovor o nalogu. Ukoliko ugovorom nisu

31 Pogledaj novi članak 12.a stavak 6. koji zamjenjuje brisani stavak 3. 
regulirane neke bitne stavke, vrijede odredbe Zakona o radu i Zakona o obveznim odnosima.

(stavak 7) (novi stavak) U slučaju spora između trenera te sportaša i ostalih osoba involviranih u konkretni pravni odnos, zbog nestručnog i neadekvatnog rada iz stavka 1. ovoga članka te neizvršavanja obveza iz sportskog ugovora, Sportski sud je nadležan utvrditi sve činjenice i okolnosti slučaja koje su dovele do spora i odrediti sankciju odgovornoj osobi.

\section{Menadžer u sportu Članak 12.}

(1) Menadžer u sportu, u smislu ovoga Zakona, osoba je koja je prema pravilima nacionalnog saveza ovlaštena obavljati poslove posredovanja prelaska sportaša iz jednoga sportskog kluba u drugi sportski klub. Isto tako, menadžer na temelju sportskoga ugovora može posredovati i zastupati sportaša i trenera u svim pravnim poslovima koji su u svezi sa sportom.

(stavak 3) (novi stavak) U slučaju spora zbog neizvršavanja ugovorenih obveza iz stavka 1. ovoga članka između menadžera te sportaša, trenera, sportskog kluba i ostalih osoba involviranih u konkretni pravni odnos, Sportski sud je nadležan utvrditi sve činjenice i okolnosti slučaja koje su dovele do spora te odrediti sankciju odgovornoj osobi.

\section{Ugovori u sportu i nadležnost suda \\ Članak 12. a (novi članak)}

(1) U pravnim odnosima sklapanja sportskih ugovora u profesionalnom sportu zastupljeni su sljedeći ugovori za koje se uplaćuje doprinos za obvezna osiguranja:

1. ugovor o profesionalnom igranju,

2. ugovor o radu,

3. ugovor o djelu,

4. ugovor o nalogu,

5. ugovor o sportskopravnom odnosu. ${ }^{32}$

(2) Moguće je sklopiti i amaterski ugovor o igranju kao dodatnoj djelatnosti i ugovor o sportskom usavršavanju i stipendiranju za koje se ne uplaćuje doprinos za obvezna osiguranja.

(3) U sportskome ugovoru, bez obzira na to radi li se o pravnom odnosu sportaša i sportske udruge, sportaša i trenera, sportaša i menadžera te sportaša i sponzora, mora biti jasno definirano koja je financijska obveza sportske udruge, menadžera i sponzora

32 U svijetu profesionalnog sporta uobičajeno je da sportske udruge i sportaši kao fizičke osobe sklapaju ugovore o sportskopravnom odnosu. To se prvenstveno odnosi na angažiranje posebnih sportskih savjetnika koji daju smjernice u radu stručnom osoblju fizičke ili pravne osobe, kako u pripremnoj fazi za sportska natjecanja, tako i prilikom sudjelovanja na sportskim natjecanjima. Kao primjer može poslužiti profesionalni tenis. 
prema sportašu odnosno sportaša prema treneru ili menadžeru, ako ga je on angažirao kao poslodavac.

(4) Ukoliko jedna od stranaka (štetnik) ne izvršava svoju ugovorenu financijsku obvezu, druga stranka (oštećenik) može tražiti raskid ugovora na štetu odgovorne osobe štetnika.

(5) Stranke su slobodne ugovarati sve uvjete koji nisu protivni zakonima i podzakonskim aktima Republike Hrvatske.

(6) Status profesionalnog sportaša, sportske udruge, trenera, menadžera i sponzora, kao i njihova prava i obveze, uređuju se konkretnim sportskim ugovorom.

(7) U svim slučajevima spora između stranaka iz sportskog ugovora i pokretanja parnice te spora koji proizlaze iz ostalih sportskopravnih odnosa, a ne odnose se na kaznena i prekršajna djela u sportu, stvarno je nadležan specijalizirani Sportski sud, ustrojen prema članku 13. ovoga Zakona. Sportski sud stvarno je nadležan i za slučajeve nesavjesnog i nemarnog izvršavanja radne obveze i nepoštovanja propisane radne discipline. ${ }^{33}$

(8) Sportski sud ovlašten je odrediti sankcije u svim slučajevima za koje je stvarno nadležan.

(9) Za slučajeve kaznenih i prekršajnih djela iz članka 12.b. ovoga Zakona stvarno je nadležan redovni sud.

(10) Redovni sud određuje i vremenski rok kao sankciju, za čijeg se trajanja takva osoba udaljava iz sportskih aktivnosti.

(11) Sankcija odnosno vremenski rok, za čijeg se trajanja takva osoba udaljava iz sportskih aktivnosti, ovisi o težini počinjenog kaznenog ili prekršajnog djela u svakom konkretnom slučaju.

Bivši članak 13. Pravne posljedice pravomoćne osude, vođenja kaznenog i prekršajnog postupka postaje članak 12. b.

\section{Sudska regulacija pravnih odnosa u sportu}

\section{Članak 13. Sportski sud (novi članak)}

(1) Sportski sud stvarno je nadležan za sve slučajeve koji proizlaze iz sportskopravnih odnosa u kojima barem jedna od stranaka obavlja sportsku djelatnost ili djelatnost u svezi sa sportom te je upisana u hrvatski registar sportskih udruga.

(2) Sukladno stavku 1. ovoga članka, Sportski sud kao specijalizirani sud stvarno je nadležan za rješavanje sporova između sportaša, fizičkih i pravnih osoba koje obavljaju sportsku djelatnost te sportskih udruga, ako zakonom nije određeno da za odlučivanje u određenoj vrsti takvih sporova postoji isključiva nadležnost redovnog suda u Republici Hrvatskoj.

33 Slučajevi povrede propisane radne discipline: npr. kad sportaš odbija izvršavati svoju radnu obvezu treniranja i sudjelovanja na natjecanjima, bez nekog opravdanog razloga, ili kad trener ne dolazi na trening bez opravdanja. 
(3) Pored stvarne nadležnosti iz stavaka 1. i 2. ovoga članka, Sportski sud postupa i po odredbama članka 21. a (novi članak) Zakona o sudovima te članka 34. d (novi članak) Zakona o parničnom postupku.

(4) Visoki sportski sud postupa po odredbama članka 26. a (novi članak) Zakona o sudovima i članka 34.e (novi članak) Zakona o parničnom postupku.

\section{Sastav Sportskog suda \\ Članak 13.a (novi članak)}

(1) Sportski sud sastavljen je od sudaca koji dobro poznaju stručne zakonitosti sporta i njegove specifičnosti.

(2) Suci Sportskog suda mogu biti i bivši sportaši pravne struke s barem petnaestogodišnjim iskustvom aktivnog bavljenja sportom.

(3) Suci iz stavaka 1. i 2. ovoga članka moraju svoju stručnost za vođenje postupka dokazati određenim ispravama izdanima od nadležnih institucija.

(4) Suci u postupku, ako je to potrebno, mogu koristiti sudske savjetnike, vještake i ostale osobe kao specijaliste za pojedine sportove.

\section{ZAKLJUČAK}

Od antičkih vremena pa do današnjih civiliziranih društava sport predstavlja globalni fenomen i djelatnost od posebnog društvenog interesa. Tako je sport tretiran i u Hrvatskoj, kako utvrđuje Ustav Republike Hrvatske. Zato je pravno nedopustivo da je temeljni zakonski akt kao lex specialis - Zakon o sportu tako koncipiran da je prepun pravnih nedorečenosti i praznina. Posebno se to odnosi na ugovor kao glavni segment u profesionalnom sportu na kojem se bazira svaki pravni odnos svih osoba involviranih u sport i djelatnosti u svezi sa sportom. Neutvrđenost zakonskog okvira i uvjeta po kojima bi se sklapali ugovori dovodi do čestih prijepora među subjektima pravnih odnosa u sportu. Tamo gdje se vrte velike svote novca legalnog i nelegalnog porijekla, radi atraktivnosti sportskih natjecanja i globalnog značaja, dolazi i do prijepora koji su u nadležnosti neadekvatnih sudskih tijela. Naime, redovni sudovi i ugovorene arbitraže koje vode ovakve sporove pokazale su određenu neefikasnost. Sportski needucirani suci, naročito suci redovnih sudova, koji ne moraju poznavati zakonitosti i specifičnosti sporta uzrok su dugogodišnjih parnica koje djeluju negativno na karijeru involviranih osoba u tom sporu. U praksi postoje primjeri višegodišnjih parnica koje su uništile sportske karijere mnogih profesionalnih sportaša. ${ }^{34}$ Osim toga, čudno je da su i maloljetni sportaši neutvrđen pojam u zakonu, a predstavljaju bitan faktor sporta općenito. Mnogi maloljetni sportaši članovi su poznatih i profitabilnih sportskih udruga, a i maloljetni sportaši u individualnim sportovima značajan su nezaobilazan faktor u sportu. Jedino rješenje ovakve situacije jest uvođenje u pravni sustav, od strane

34 Vidi supra bilj. br. 12. 
Mr. sc. Dean Vuleta: Pravne posljedice neadekvatnog treninga i metoda rada u sportu te zakonske novele... Zbornik radova Pravnog fakulteta u Splitu, god. 56, 3/2019, str. 627-647

zakonodavca, novih specijaliziranih sportskih sudova koji bi bili stvarno nadležni za sve što se odnosi na sportskopravne odnose. Uostalom, Zakon o sudovima u čl. 14. st. 5. predviđa mogućnost uvođenja u pravni sustav novih specijaliziranih sudova, ako za to postoji potreba s obzirom na globalni značaj sporta i specifične odnose koji vladaju u njemu. U takvom slučaju vrhunski sport, sportaši i cjelokupna sportska djelatnost imali bi velike koristi u rješavanju merituma spora u razumnom vremenskom periodu, u skladu s ostvarenjem načela pravičnosti i zakonitosti.

\section{LEGAL CONSEQUENCES OF INADEQUATE TRAINING AND METHODS OF WORK IN SPORTS AND LEGAL NOVELTIES OF SOME UNDEFINED TERMS IN DE LEGE FERENDA}

The complexity of legal relationships and specific situations that are possible in sport and sport activities and the actors of such situations require additional legal regulation and supplementation of existing legal norms and legal acts: sports, compulsory, civil, labor, medical, criminal, judicial and other legal branches, directly and indirectly related to sport. Apart from all the rules applicable to sport, the legislator has failed to establish and standardize a relatively common phenomenon in modern sports, which is the sporting and legal consequences of inadequate training and methods of work. This primarily refers to anxiety and various sports injuries as well as possible secondary personality injuries as a result of impractical work (psychological instability, athlete's depression and fear of losing a sports career). Non-professional work leads to short-term cessation of sports activities due to overt and various injuries (sports injuries and accompanying personality injuries), and in the long run and until the end of the sports career. The existence of all persons involved in such cases can potentially be compromised. Responsible culprits in such cases (coaches, managers, sponsors, doctors, and others) must have legal consequences through property, criminal, and other sanctions. What are the legal consequences of such cases and who is obliged to determine the default of the legislative authority. The legislator should initiate an initiative to introduce into the legal system of new specialized judicial bodies. Such sports courts were legally competent to identify, misdiagnosise and sanction the consequences of improper work in sports, as well as for all other sporting and sporting events. This would have to happen through legal novelties that would fill the present legal gaps and improprieties and cause reparations to the provisions of some legal acts, primarily the Sports Act. Sports courts would be competent solely in all sport-related disputes except in the case of offenses punishable by sport in which a prison sentence is envisaged. It would consist of legal professionals who are well aware of the professionalism of sport and its specificity as human activities, ie former athletes of legal profession and other persons (eg expert witnesses) who are specialists in certain sports. Such cases are currently under the jurisdiction of regular courts, and this situation leads to lengthy disputes and litigation and high costs of the involved actors and the state. Regular court judges (municipal and county) do not have to know the sport and its specificity and legality.

Key words: athletes, sports agreement, sports and legal consequences of inadequacy, specialized sports court, sports law, legal novels 